Research Article

\title{
Deformation Law and Control Measures of Gob-Side Entry Filled with Gangue in Deep Gobs: A Case Study
}

\author{
Xun Liu (iD, Shihao Tu (D), Dingyi Hao, Yida Lu, Kaijun Miao, and Wenlong Li \\ School of Mines, China University of Mining and Technology, Xuzhou 221116, China \\ Correspondence should be addressed to Shihao Tu; tsh@cumt.edu.cn
}

Received 23 March 2021; Accepted 8 May 2021; Published 18 May 2021

Academic Editor: Xianjie Hao

Copyright (c) 2021 Xun Liu et al. This is an open access article distributed under the Creative Commons Attribution License, which permits unrestricted use, distribution, and reproduction in any medium, provided the original work is properly cited.

\begin{abstract}
Aiming at the large deformation problem of gob-side entry in solid filling mining, the roof subsidence of gob-side entry retaining (GER) was studied under the influence of gangue filling, by taking a deep filling working face in Shandong Province as the engineering background and using theoretical derivation as well as FLAC3D numerical simulation. Research shows that the stiffness of the gangue filling body in the gob and the stiffness and width of the entry protection coal and rock mass (EPCARM) are positively correlated with the GER roof subsidence, which is much less affected by the EPCARM parameters than by the GER stiffness. The GER failure to meet the application requirements is mainly attributed to the insufficient stiffness of the gangue filling body and excessive advance subsidence, which inhibit the roof stress transfer. The GER replacement by the gobside entry driving (GED) scheme, which implies replacing the entry protection gangue bag wall with the coal pillar with a width of $5 \mathrm{~m}$, will reduce the roof subsidence to $0.114 \mathrm{~m}$, according to the proposed equation. The results obtained are considered quite instrumental in deformation control of the gob-side entry filled with gangue, as well as substantiation of GED and GER applicability options.
\end{abstract}

\section{Introduction}

With increasing coal mining intensity and gradual exhaustion of shallow resources, deep mining became a global trend $[1,2]$. However, due to the high frequency of deep mining disasters, it is faced with severe challenges, and some scholars have also done much basic research [3-6]. Gangue solid filling is one of the main technologies used to solve the deep mining problems: it plays a significant role in the control of rock strata and effective utilization of the gangue, effectively controls the surface deformation and stratum fracture, reduces the ground damage, consumes the gangue on the ground and underground, and abates the gangue occupation and pollution [7-11]. In particular, the gob-side entry retaining (GER) has been widely used in China due to its great contribution to improving the stress environment of the entry and increasing the coal resource recovery rate [12-15]. Moreover, with the global expansion of the filling technology, the GER has gradually been applied in the deep filling face [16-20].
At present, many scholars have analyzed the GER with gangue filling from the aspects of strength and width of the roadside filling mass, entry support measures, and filling rate of the gob. For example, Ju et al. [21] analyzed the stress characteristics of roadside filling mass under compaction conditions and used the numerical simulation to assess the GER, the strength of the gangue belt, and the width-toheight ratio. Deng et al. [22] studied the deviatoric stress evolution characteristics of surrounding rock of the gob-side entry and optimized the GER parameters under different values of buried depth, gob filling ratio, width, and strength of the roadside filling mass. Huang et al. [23] considered that reasonable selection of mining, filling, and retaining technology, reliable support form, and reasonable combined support scheme are the key to the successful GER implementation. Gong [24] analyzed the deformation characteristics of the entry retaining roof and the roadside support body, proposed the flexible roadside support scheme of "gangue belt + reinforcement + guniting," and verified the correctness of this support scheme on-site. Chen et al. [25] 
proposed the entry retaining technology combining the gangue belt with the grouting while considering the difficulties of filling the GER and determined the reasonable width of the gangue bag by numerical simulation. Yu et al. $[26,27]$ carried out a series of mechanical tests of rock-coalbolt (RCB) composite system for the complex nonlinear rock mechanics characteristics of deep coal mine and considered that the combination angle and bolt have a great influence on the combination system.

Since the roadside filling body and coal pillars are used for the gob-side entry protection, they are jointly referred to as "entry protection coal and rock mass" (EPCARM). The solid backfill mining involving gob-side entry is generally divided into gob-side entry driving (GED) and gob-side entry retaining (GER) techniques [28, 29]. Although the former (GED) technique combines the advantages of filling and entry retaining, the most frequent stress environment of the EPCARM is not favorable for its application, and the current research efforts are mainly focused on the GER. A field investigation of the GER in 2305S-2\# and 1302N-2\# working faces of a particular coal mine in the Shandong Province of China revealed several sections with serious deformation, despite the application of such preventive measures as support strengthening and increased EPCARM width. A simple and accurate roof subsidence prediction model is topical to guide the deformation control of the gobside entry in the gangue filling face, comprehensively study the deformation mechanism of the gob-side entry under the filling condition, and substantiate the effective control countermeasures. Given this, this study was aimed to develop and validate a mechanical model of gob-side entry for the EPCARM parameters determined in the above mine, which integrated deep mining, dressing, and filling techniques. The influencing factors of the gob-side entry deformation were analyzed to provide a reference for surrounding rock control of the deep gob-side entry.

\section{Project Overview}

The 1302N-2\# filling face of deep mining, dressing, and filling integrated mine in Shandong Province of China was used in this study as the engineering background. The mine layout featured the $1303 \mathrm{~N}-1 \#$ working face in the west, the gob of the $1302 \mathrm{~N}-2$ \# filling face in the east, the old gob of the $1302 \mathrm{~N}$ working face in the north, and the village protection pillar in the south. The mining depth of the working face was $736 \mathrm{~m}$, which corresponded to deep mining conditions. The minable coal seam was No. 3 upper coal seam, with an average thickness of $2.7 \mathrm{~m}$. The working face was mined along the strike, with a strike length of $482 \mathrm{~m}$, an inclined length of $85 \mathrm{~m}$, and a seam dip angle ranging from $1^{\circ}$ to $12^{\circ}$. The gob of the filling face was filled with solid gangue, the upper entry was retained along the gob, the entry was driven along the roof of the coal seam, and the mudstone floor was broken. The entry cross-section was rectangular, with actual width of $4.7 \mathrm{~m}$ and a net height of $3.7 \mathrm{~m}$. The "bolt + anchor cable + steel belt" support scheme was adopted. The $20 \mathrm{~m}$ thick immediate roof was siltstone, the $4 \mathrm{~m}$ thick main roof was fine-grained sandstone, and the $1.5 \mathrm{~m}$ thick immediate floor was mudstone. Besides the gob-side entry, a stacked gangue bag wall, installed cement pier column, and anchor cable support were employed. The building width ranged from 2 to $3 \mathrm{~m}$, and the entry layout is depicted in Figure 1 .

The entry deformation was mainly manifested by largeangle rotary subsidence of the roof, bulging and falling of the gangue wall, and strong floor heave. The latter was the most prominent feature of the entry, exhibiting the largest deformation among mining entries in this mine. However, after the floor leveling and implementation of the monorail crane technology in the mine, the floor heave was mitigated and had little impact on the mine production. The largeangle rotary subsidence occurred in the sections with a lower filling rate, accompanied by the gangue wall bulging and falling. The gangue bag for entry protection was not used in some sections due to their large rotary subsidence. Noteworthy is that the large depth and rotary subsidence of the mine made it quite problematic to improve the filling rate in front of the gob. This paper mainly analyzes the roof subsidence and the deformation of entry protection coal and rock mass based on the above field investigation.

\section{Analysis of Factors Influencing the Gob-Side Entry Roof Subsidence}

3.1. Mechanical Model Elaboration. Large deformation of EPCARM affects the gob-entry side stability, strongly deteriorates its stress and strain state, and can result in the entry roof collapse. Therefore, deformation characteristics of the EPCARM should be considered to analyze the surrounding rock stability. In the integrated mine, shortage of gangue supply, untimely filling, and low advancing speed of the working face, resulting in the insufficient filling rate of the gob, may lead to breaking the immediate roof. The latter phenomenon can be analyzed using the conventional mechanical model of the gob-side entry. Therefore, further theoretical analysis only considers the situation where the immediate roof is not broken. The mechanical model of the gob-side entry, which envisaged the interaction between the roof and filling body under the filling condition, was elaborated, as shown in Figure 2.

The original model was simplified as follows. The EPCARM right roof was taken as the coordinate origin, and the overlying strata load on the roof was assumed to be uniformly distributed. Insofar as the right gangue filling area approximately satisfied the Winkler elastic foundation requirements, it was treated as a beam model on the elastic foundation. Taking the gob length along the entry direction as the unit length, the EPCARM current deformation as $\Delta h_{0}$, and the under top-filling amount between the gob roof and filling body (relative to EPCARM) as $U_{0}$, the total gob subsidence can be derived as $\Delta h=\Delta h_{0}+U_{0}$. According to the elastic foundation beam theory, the deflection equation of roof subsidence has the following form: 


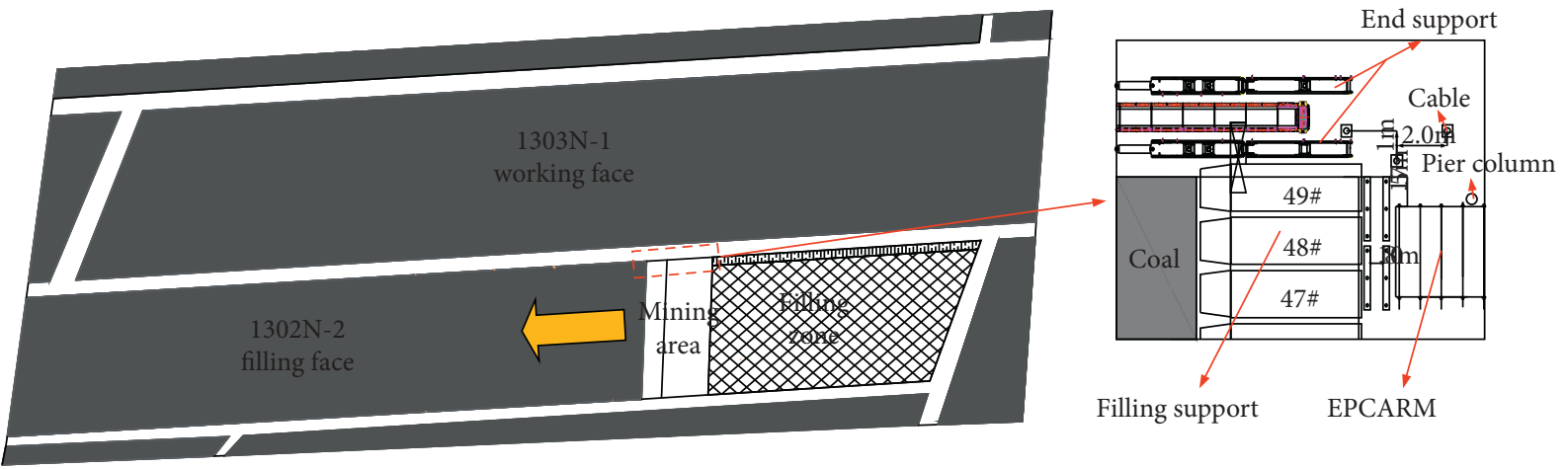

Figure 1: The filling gob-side entry layout.

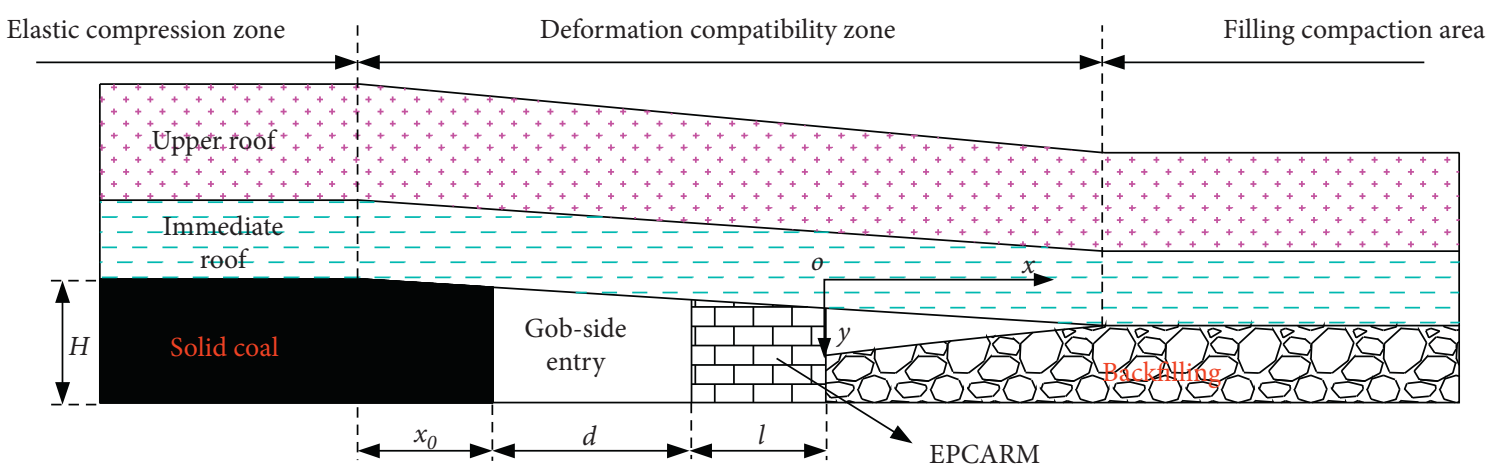

FIgURE 2: Partition model of interaction between the roof and filling body under the filling condition.

$$
\left\{\begin{array}{l}
w(x)=e^{-\alpha x}(A \cos \alpha x+B \sin \alpha x)+\frac{q}{k_{c}}+\Delta h_{0}+U_{0}(x \geq 0), \\
w(x)=e^{\beta x}(C \cos \beta x+D \sin \beta x)+e^{-\beta x}(E \cos \beta x+F \sin \beta x)+\frac{q}{k_{h}}(-l \leq x \leq 0),
\end{array}\right.
$$

where $\alpha=\sqrt[4]{k_{c} / 4 \mathrm{EI}} ; \beta=\sqrt[4]{k_{h} / 4 \mathrm{EI}} ; \quad k_{c}$ and $k_{h}$ are elastic foundation coefficients of the gob and the coal and rock mass, respectively; $E$ and $I$ are the elastic modulus and moment of inertia of the immediate direct roof, respectively; $q$ is the overlying load of the immediate roof; and $A, B, C, D$, $E$, and $F$ are unknown constant coefficients.

According to available research results, there is little difference between the strength of EPCARM and that of the coal body. Therefore, to simplify the above formula, the EPCARM was considered equivalent to the coal body. The gob portion with $x \leq 0$ was regarded as a semi-infinite elastic foundation beam, with zero $E$ and $F$ coefficients. Since $w(x)$ measures the magnitude of a disturbance (i.e., deformation) that is traveling in an elastic material, at $x=0$, the disturbance of equation (1) is $\Delta h_{0}$. Using the above boundary conditions, the unknown coefficients can be derived.

The deflection curve equation of roof subsidence can be obtained by substituting $w(0)=\Delta h_{0}$ into equation (1). Thus, at $x=0$, we have

$$
\Delta h_{0}=\frac{q}{k_{h}}+\frac{\alpha^{2} q}{\beta^{2} k_{c}} .
$$

At $x \leq 0$, it is quite problematic to determine $U_{0}$. According to the field investigation, the roof of the gob-side entry filled in the deformation control zone is characterized by uniform subsidence without obvious bending, so the deflection variation of the gob-side entry roof in the above zone can be regarded as linear. Therefore, according to the geometric considerations, the compressive deformations of the two sides of the entry after compression of the EPCARM are as follows:

$$
\left\{\begin{array}{l}
\Delta h_{1}=\left(x_{0}+d\right) \tan \theta, \\
\Delta h_{2}=\left(x_{0}+d+l\right) \tan \theta,
\end{array}\right.
$$

where $\Delta h_{1}$ is the roof subsidence at the entry side of the coal and rock mass, $\Delta h_{2}$ the roof subsidence at the gob side of the coal and rock mass, $\theta$ the rotation angle of rock stratum, $x_{0}$ the width of the plastic zone at the solid coal side of the gobside entry, $d$ the width of entry, and $l$ the width of the coal and rock mass. At $x=0$, we get $\Delta h_{0}=\Delta h_{2}$. Combining equations (2) and (3) yields

$$
\Delta h_{1}=\frac{q\left(x_{0}+d\right)}{x_{0}+d+l}\left(\frac{1}{k_{h}}+\frac{1}{\sqrt{k_{c} k_{h}}}\right) \text {. }
$$


Since the filling body in the gob is loose medium with small thickness, its elastic foundation coefficient can be approximately assessed as follows:

$$
\left\{\begin{array}{l}
k_{h}=\frac{E_{h}}{h_{0}}, \\
k_{c}=\frac{E_{c}}{h_{0}},
\end{array}\right.
$$

where $E_{h}$ and $E_{c}$ are the foundation stiffness values (elastic moduli) of the EPCARM and the gob filling body [30], respectively, whereas $h_{0}$ is the foundation thickness. By substituting equation (5) into equation (4), the following relationship between the entry side roof subsidence of the EPCARM and the foundation stiffness values of the EPCARM and the gob filling body can be obtained.

$$
\Delta h_{1}=\frac{q\left(x_{0}+d\right) h_{0}}{x_{0}+d+l}\left(\frac{1}{E_{h}}+\frac{1}{\sqrt{E_{c} E_{h}}}\right) .
$$

3.2. Analysis of Factors Influencing the Roof Subsidence and Gob-Side Entry Deformation. For the filled gob-side entry under study, the plastic zone width $x_{0}$ in the solid coal wall can be calculated as follows [31]:

$$
x_{0}=\frac{\lambda h}{2 \tan \varphi_{0}} \ln \left[\frac{k \gamma H+\left(c_{0} / \tan \varphi_{0}\right)}{\left(c_{0} / \tan \varphi_{0}\right)+\left(p_{0} / \lambda\right)}\right],
$$

where $\lambda$ is the lateral pressure coefficient equal to $0.41 ; \varphi_{0}$ and $c_{0}$ are the internal friction angle and cohesion, respectively, of the interface between the coal seam, roof, and floor, which are assumed to be $25^{\circ}$ and $2 \mathrm{MPa}$, respectively; $k$ is the stress concentration factor, which is equal to $1.7 ; \gamma$ is the average unit weight of the overlying strata; $H$ is the buried depth of entry $(736 \mathrm{~m})$; and $p_{0}$ is the support strength of entry protection $(0.2 \mathrm{MPa})$. Substitution of the above values into equation (7) yields $x_{0}=3.4 \mathrm{~m}$.

The entry width $d$, the overlying load $q$ of the immediate roof, and the actual mining height $H$ generally exhibit slight variations. Therefore, according to equation (6), the maximum subsidence of the entry roof is related to foundation stiffness values of the EPCARM $\left(E_{h}\right)$ and gob $\left(E_{c}\right)$, and the width $l$ of coal and rock mass. Using the field mining conditions, namely, $d=5 \mathrm{~m}$, $q=18.4 \times 10^{6} \mathrm{~N} / \mathrm{m}, H=3.7 \mathrm{~m}, E_{h}=0.5 \mathrm{GPa}, E_{c}=0.1 \mathrm{GPa}$, $h_{0}=3.6 \mathrm{~m}$, and $l=2 \mathrm{~m}$, we get the roof subsidence of $0.346 \mathrm{~m}$, which is consistent with the deformation in most areas of the site, indicating the accuracy of equation (6). The effects of human-controllable factors $E_{h}, E_{c}$, and $l$ on the roof subsidence of the gob-side entry are depicted in Figure 3.

As shown in Figures 3(a) and 3(b), the maximum roof subsidence of the gob-side entry is negatively correlated with the foundation stiffness of the EPCARM and the filling body in the gob. Given the variety of materials that can be applied, the foundation stiffness of the EPCARM varies widely. If this value is less than $1 \mathrm{GPa}$, the roof subsidence ranges between
0.223 and $0.552 \mathrm{~m}$. If $E_{h}$ is increased from 0.25 to $1.0 \mathrm{GPa}$, the roof subsidence becomes quite significant. If $E_{h}$ is increased from 1 to $4 \mathrm{GPa}$, that is, by four times, the roof subsidence drops from 0.223 to $0.098 \mathrm{~m}$, which corresponds to a $22 \%$ decline, which is quite small. Similarly, the roof subsidence of $0.35 \mathrm{~m}$ is observed at $E_{c}=0.1 \mathrm{GPa}$ versus $0.45 \mathrm{~m}$ at $E_{c}=0.05 \mathrm{GPa}$, which implies a difference of $0.1 \mathrm{~m}$ and a strong effect of $E_{\mathrm{c}}$ variation on the roof subsidence. If $E_{c}$ is increased by $300 \%$, from 0.1 to $0.4 \mathrm{GPa}$, the roof subsidence drops from 0.346 to $0.227 \mathrm{~m}$, that is, by $34 \%$. In this case, a variation of the foundation stiffness of the filling body in the gob has a weaker effect on the roof subsidence of the gob-side entry than that of the coal and rock mass. When the foundation stiffness values of the filling body in the gob and the EPCARM exceed a certain level, their effects on the deformation control of the roof are no longer significant. With an increase in the width $l$ of the coal and rock mass, the roof subsidence decreases linearly, but slightly; when the EPCARM width is increased from 1 to $4 \mathrm{~m}$, the roof subsidence drops from 0.383 to $0.290 \mathrm{~m}$, that is, only by $24 \%$, as shown in Figure 3(c).

\section{Deformation and Stress Distribution of Gob- Side Entry}

4.1. Numerical Simulation. According to the field investigation, roofs of some sections experienced large subsidence in advance, and the roof was severely deformed before entry retaining. After retaining, high rotary stresses act on the coal and rock mass, resulting in large deformation. At this time, increasing the foundation stiffness of the EPCARM and the gob filling body could not effectively control the surrounding rock deformation. Additionally, the advance roof subsidence effect was not considered in the above analysis. The numerical simulation method was adopted to verify the accuracy of the proposed equation and assess the roof subsidence effect.

The FLAC3D software was used to establish a threedimensional numerical model simulating the $1302 \mathrm{~N}-2 \#$ working face of the mine under study. The model dimensions were $300 \mathrm{~m} \times 200 \mathrm{~m} \times 73.5 \mathrm{~m}$, the coal seam dip angle was $11^{\circ}$, and the working face length was only $85 \mathrm{~m}$. Therefore, the effect of the working face dip angle was negligible and could be ignored.

The common Mohr-Coulomb criterion was applied for rock mass [32, 33]. Considering the compaction characteristics of the rock mass in the filling area, the double-yield model or the elastic model are generally used for simulation [34]. However, since the double-yield model parameters are complex, and their adjustment is quite cumbersome, the elastic model is employed for simulation. The elastic modulus of the filling body was not constant during compaction and, therefore, had to be adjusted twice in calculations via the elastic model.

Numerical simulations via FLAC3D adopted the wellknown relationships between the elastic modulus $E$, bulk modulus $K$, shear modulus $G$, and Poisson's ratio $\mu$, namely, 


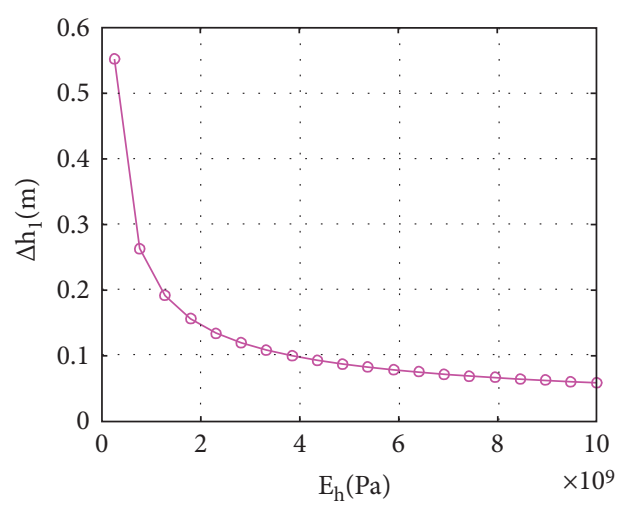

(a)

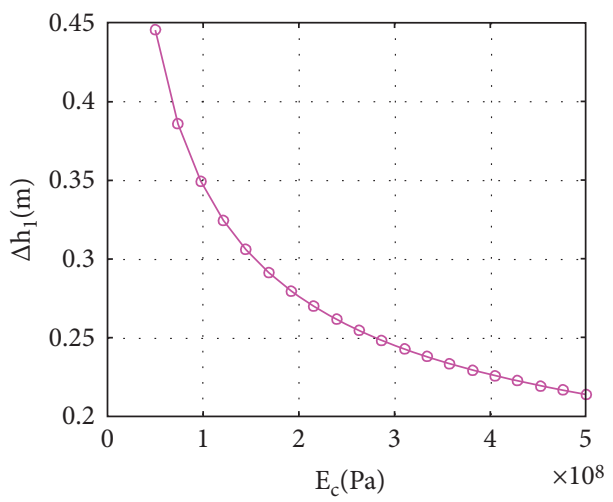

(b)

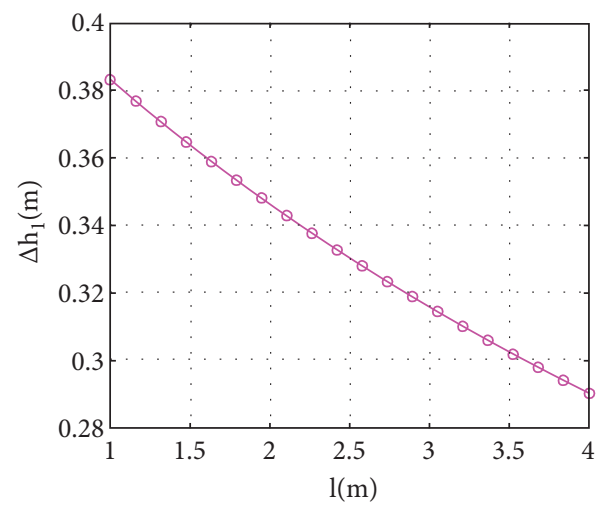

(c)

FIGURE 3: Effect of human-controllable factors on roof subsidence of gob-side entry. (a) EPCARM. (b) Filling body in the gob. (c) Width of EPCARM.

$$
\left\{\begin{array}{l}
K=\frac{E}{3(1-2 \mu)}, \\
G=\frac{E}{2(1+\mu)} .
\end{array}\right.
$$

According to the Salamon theory $[35,36]$, the stressstrain relationship of the gangue filling body during compaction is as follows:

$$
\sigma=\frac{E_{0} \varepsilon}{(1-\varepsilon) / \varepsilon_{m}},
$$

where $\sigma$ is the vertical stress of the gob, $E_{0}$ the initial foundation stiffness of the gangue filling body, $\varepsilon$ the current vertical strain, and $\varepsilon_{m}$ the maximum vertical strain.

According to the study conducted by Yavuz [37], $\varepsilon_{m}$ can be expressed as follows:

$$
\varepsilon_{m}=\frac{(b-1)}{b}
$$

where $b$ is the comprehensive crushing expansion coefficient of the filling body, which is equal to 1.3 , according to the field conditions.

By combining equations (9) and (10), the elastic modulus $E$ can be derived:

$$
E=\frac{d \sigma}{d \varepsilon}=\frac{b(b-1) E_{0}}{(b \varepsilon-b+1)^{2}} \varepsilon-\frac{E_{0}(b-1)}{(b \varepsilon-b+1)} .
$$

It is assumed that Poisson's ratio $\mu=0.2$ [38]. Based on equations (8) and (11), the relationship between the bulk modulus $K$, shear modulus $G$, and vertical strain $\varepsilon$ can be obtained.

Since the filling material is bulk material, the elastic modulus should be reduced when the elastic model is applied. According to the study by Mitri et al. [39], the relationship between rock mass and elastic modulus of the laboratory specimen is as follows:

$$
\frac{E_{\mathrm{rm}}}{E_{\mathrm{lab}}}=0.5\left[1-\cos \left(\pi \frac{\mathrm{GSI}+5}{100}\right)\right],
$$

where $E_{\mathrm{rm}}$ and $E_{\mathrm{lab}}$ are elastic moduli of rock mass and laboratory specimen, respectively, and GSI is the geological strength index. According to the study by Hoek et al. [40], the GSI of gangue bulk is 10, so the elastic modulus of the gangue filling body in the numerical simulation is 0.054 times the initial one, and the rock parameters are as shown in Table 1.

Using the software with code in the FISH language, the vertical strain was monitored for each time step (of the total 100 steps used in this study), and its value was substituted 
TABLE 1: Rock mass parameters.

\begin{tabular}{|c|c|c|c|c|c|c|}
\hline Lithology & $\begin{array}{l}\text { Bulk modulus } \\
\text { (GPa) }\end{array}$ & $\begin{array}{l}\text { Shear modulus } \\
(\mathrm{GPa})\end{array}$ & $\begin{array}{l}\text { Density } \\
\left(\mathrm{kg} \bullet \mathrm{m}^{-3}\right)\end{array}$ & $\begin{array}{l}\text { Cohesion } \\
(\mathrm{MPa})\end{array}$ & $\begin{array}{c}\text { Internal friction } \\
\text { angle }\left({ }^{\circ}\right)\end{array}$ & $\begin{array}{l}\text { Tensile strength } \\
\text { (MPa) }\end{array}$ \\
\hline Mudstone & 0.9 & 0.6 & 2600 & 1.5 & 28 & 0.8 \\
\hline $\begin{array}{l}\text { Fine-grained } \\
\text { sandstone }\end{array}$ & 21.5 & 16 & 2600 & 3.2 & 35 & 1.8 \\
\hline Siltstone & 5.7 & 4 & 2550 & 2.5 & 28 & 1.3 \\
\hline Coal & 1.3 & 0.7 & 1350 & 1.7 & 25 & 0.4 \\
\hline $\begin{array}{l}\text { Medium-grained } \\
\text { sandstone }\end{array}$ & 16 & 15.5 & 2650 & 3.8 & 35 & 1.9 \\
\hline
\end{tabular}

into equations (7) and (10) to derive the bulk and shear moduli of the gangue filling body, and then it was readjusted. The elastic model was refined to realize the calculation of the filling gob compaction theory. The numerical simulation scheme is shown in Table 2. After the working face was advanced by $100 \mathrm{~m}$, a monitoring line was set in the immediate roof at 10,50, and $90 \mathrm{~m}$, respectively, behind the working face, and each line was numbered 1\#, 2\#, and 3\#, as shown in Figure 4.

The stress and roof deformation on the measuring lines were taken as indices to analyze the gob-side entry roof. Data analysis shows that the deformation and stress variation patterns of the three measuring lines were the same. Since the deformation of $1 \#$ measuring line was not stable and $3 \#$ measuring line exhibited a certain boundary effect, the data of $2 \#$ measuring line were selected for analysis.

4.2. Analysis of Numerical Simulation Results. As shown in Figure 5, with an increase in the foundation stiffness of the filling body, the vertical stress of the entry protection side and the coal wall side decreases, reflecting an obvious stress transfer effect. Among them, the filling body in the gob is subject to the most pronounced stress transfer effect. During the increase of the foundation stiffness of the filling body, the stress of the filling area increased by $2 \mathrm{MPa}$, and the vertical stress of the EPCARM dropped by about 1 and $0.5 \mathrm{MPa}$ for the coal wall side. The effect of enhancing the foundation stiffness of the filling body implied the stress transfer from the EPCARM and the coal wall side to the filling body. Similarly, with an increase in the foundation stiffness of the gangue filling body, the roof deformation of both sides was reduced, and the roof reduction of the filling area turned out to be the most significant, followed by that of the entry protection. The deformation variation of the coal wall side is smaller, which is consistent with the roof stress transfer variation.

As shown in Figure 6, with an increase in foundation stiffness of coal and rock mass, the vertical stress of EPCARM gradually increased, and the maximum value was about $25 \mathrm{MPa}$, which exceeded the strength limit of general coal and rock mass, while the stress release effect in the stress concentration area of the coal wall side was limited. As for the deformation control, the improvement of foundation stiffness of EPCARM exerted an obvious control effect on the entry roof subsidence, and the roof subsidence at the entry protection side was reduced from 313 to $204 \mathrm{~mm}$.
Therefore, a larger foundation stiffness of EPCARM can limit the entry roof subsidence, but with higher requirements for material properties (compressive strength). An appropriate foundation stiffness of EPCARM can effectively control the entry roof deformation and stress concentration.

As shown in Figure 7, the EPCARM width has little effect on the roof stress variation. An increase in width enables the stress to transfer to the gob side. The EPCARM width effect on the roof subsidence is also not obvious, which is consistent with the theoretical prediction, judging from the roof subsidence at the entry gob side, which further confirms the accuracy of equation (6).

As shown in Figure 8, an increase in the advance roof subsidence can reduce the vertical pressure of EPCARM to a certain extent. When the advance roof subsidence was increased from $0 \mathrm{~m}$ to $0.4 \mathrm{~m}$, the maximum vertical stress of EPCARM dropped from 2.7 to $0.97 \mathrm{MPa}$, while that of the coal wall side decreased from 33.8 to $28.2 \mathrm{MPa}$. Since the roof subsidence increases with advance subsidence, no excess advance subsidence is recommended.

\section{Industrial Applications}

5.1. Control Measures. According to the above analysis, when the EPCARM is a weak gangue bag wall, an adequate improvement of the EPCARM foundation stiffness can effectively control the roof subsidence, while the EPCARM width has relatively little influence on it. A change of foundation stiffness of gob filling body imposes less influence than that of coal and rock mass, and there is an obvious stiffness effect between the EPCARM and the gob filling body. The foundation stiffness of the EPCARM and the gob filling body significantly influence the roof deformation and become the key factor of roof deformation. Therefore, the following measures can be taken in practical engineering:

(1) From the perspective of foundation stiffness effect, it is recommended to optimize the following parameters: (i) filling process and particle size ratio of filling materials, (ii) support structure and selection of filling materials to ensure the filling effect, and (iii) advance direction of the working face to ensure smooth implementation of the filling technology.

(2) Either the support design should be optimized to strengthen the coal and rock mass, or the enhanced EPCARM material should be used to effectively 
TABle 2: Numerical simulation scheme.

\begin{tabular}{lcccc}
\hline Scheme & $\begin{array}{c}\text { Foundation stiffness of } \\
\text { EPCARM }(\mathrm{GPa})\end{array}$ & $\begin{array}{c}\text { Foundation stiffness of filling body in } \\
\text { gob }(\mathrm{GPa})\end{array}$ & $\begin{array}{c}\text { Width of EPCARM } \\
(\mathrm{m})\end{array}$ & $\begin{array}{c}\text { Roof subsidence in } \\
\text { advance }(\mathrm{m})\end{array}$ \\
\hline Reference & 0.5 & 0.1 & 2 & 0 \\
scheme & 0.5 & $0.1-0.5$ & 2 & 0 \\
Scheme 1 & $0.5-8.0$ & 0.1 & 2 & 0 \\
Scheme 2 & 0.5 & 0.1 & $2-5$ & 0 \\
Scheme 3 & 0.5 & 0.1 & 2 & $0-0.4$ \\
Scheme 4 & & & 2 & 0 \\
\hline
\end{tabular}

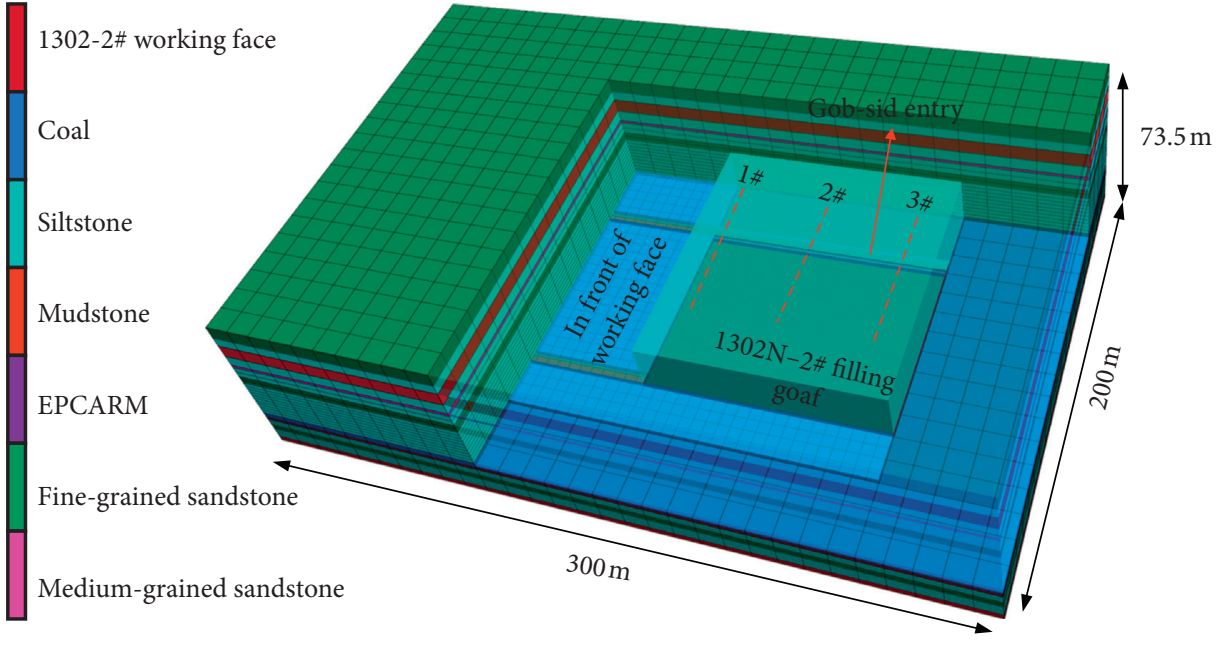

Figure 4: Numerical model.

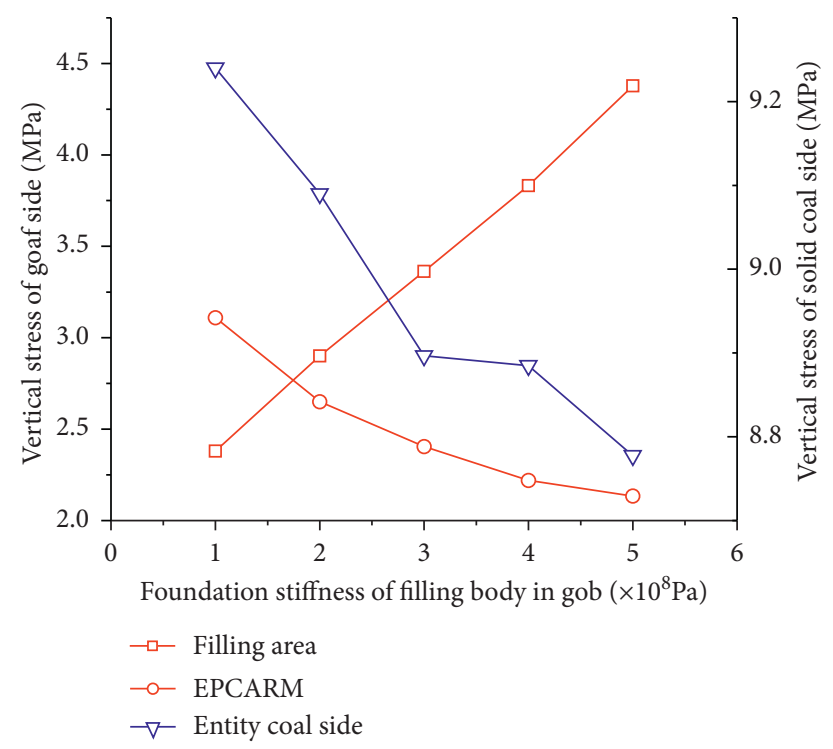

(a)

FIgURE 5: Continued. 


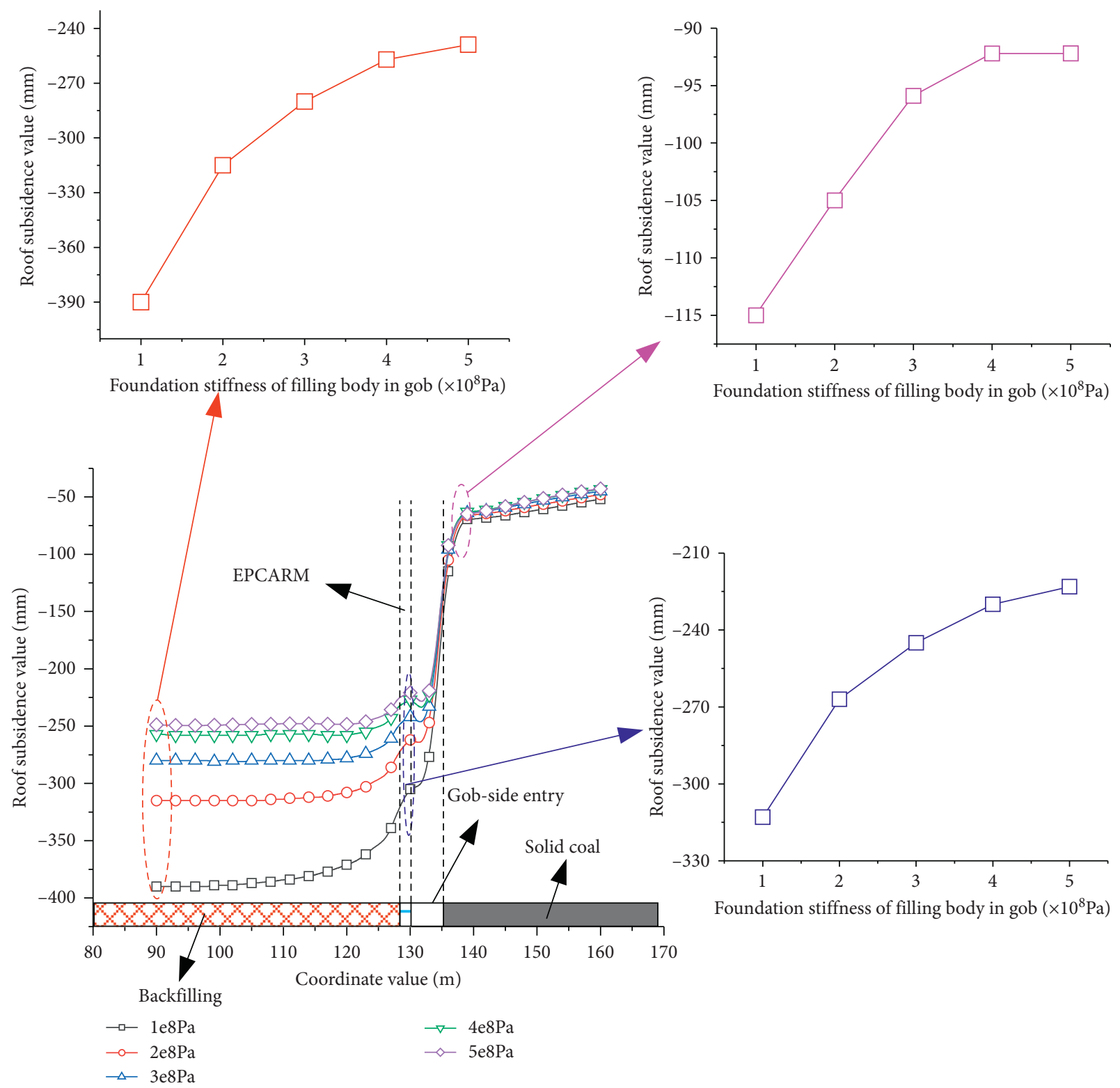

(b)

FIGURE 5: Roof deformation and stress variation for different foundation stiffness values of gob filling body. (a) Stress variation pattern. (b) Deformation variation pattern.

increase the foundation stiffness of the coal and rock mass to control the roof subsidence.

(3) The EPCARM width, despite its weak effect on the roof subsidence, plays a certain role in ensuring the integrity of coal and rock mass and can transfer the roof stress to the gob side to a certain extent. Therefore, the EPCARM width should be optimized based on the stiffness values of the gangue filling body in the gob versus coal and rock mass.

(4) The advance roof subsidence should be controlled in a small range to prevent the rotary roof subsidence, otherwise increasing the surrounding rock stress around the entry and producing large deformation.
5.2. Engineering Practice. According to the field investigation and above analysis, insufficient foundation stiffness of the gob filling body and excessive advance roof subsidence are the main reasons for poor maintenance of the GER. Due to the large deformation of the $1302 \mathrm{~N}-2$ \# working face, the GER technique should not be used to mine the next working face. Generally, the foundation stiffness of the coal body is larger than that of the gangue bag, and, therefore, the foundation stiffness of $2 \mathrm{GPa}$ was selected. Although the coal pillar width exerted little influence on the entry deformation, the width value of $5 \mathrm{~m}$ was selected and substituted into equation (6), according to the engineering experience and numerical simulation analysis considering the integrity of the coal pillar. The roof subsidence was estimated to be 


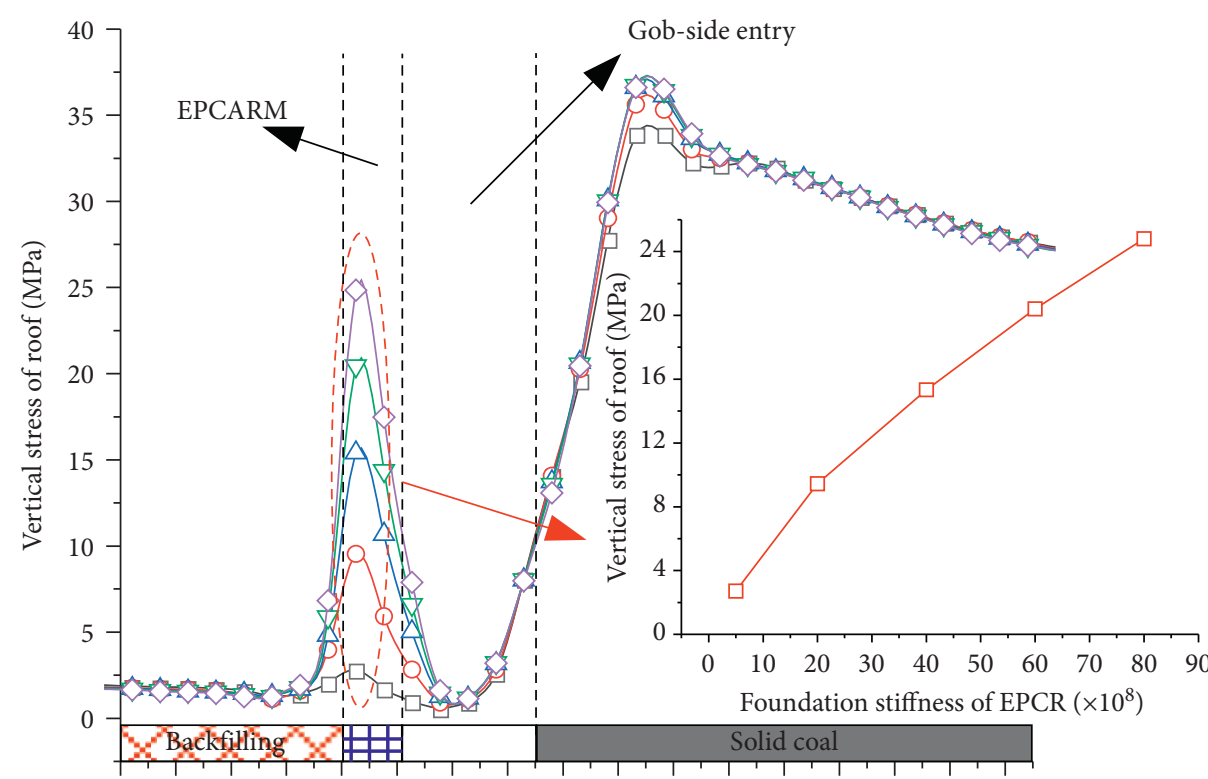

$\begin{array}{lllllllllllllllll}120 & 122 & 124 & 126 & 128 & 130 & 132 & 134 & 136 & 138 & 140 & 142 & 144 & 146 & 148 & 150 & 152\end{array}$

Coordinate value $(\mathrm{m})$

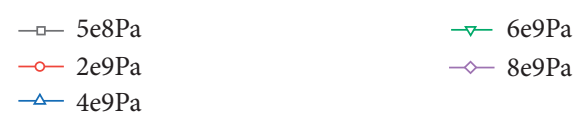

(a)

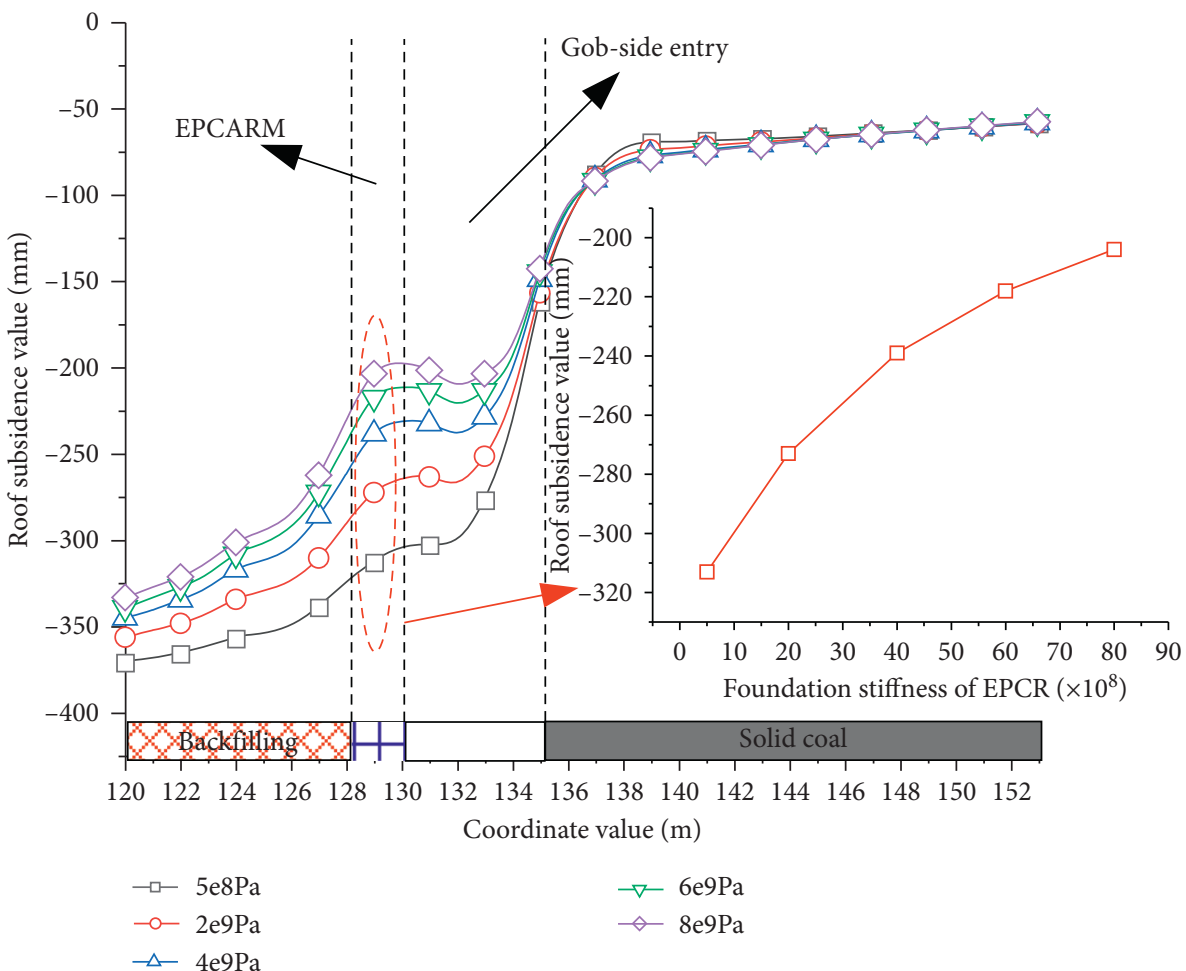

(b)

FiguRE 6: Roof deformation and stress variations for different foundation stiffness values of coal and rock mass. (a) Stress variation pattern. (b) Deformation variation pattern.

$0.114 \mathrm{~m}$, which met the respective requirements. Assuming that concrete was utilized, the foundation stiffness generally exceeded $8 \mathrm{GPa}$ [41], and the internal stress was larger as indicated by the numerical simulation, which raised higher requirements for material characteristics. Additionally, the technology of entry protection with concrete materials is 


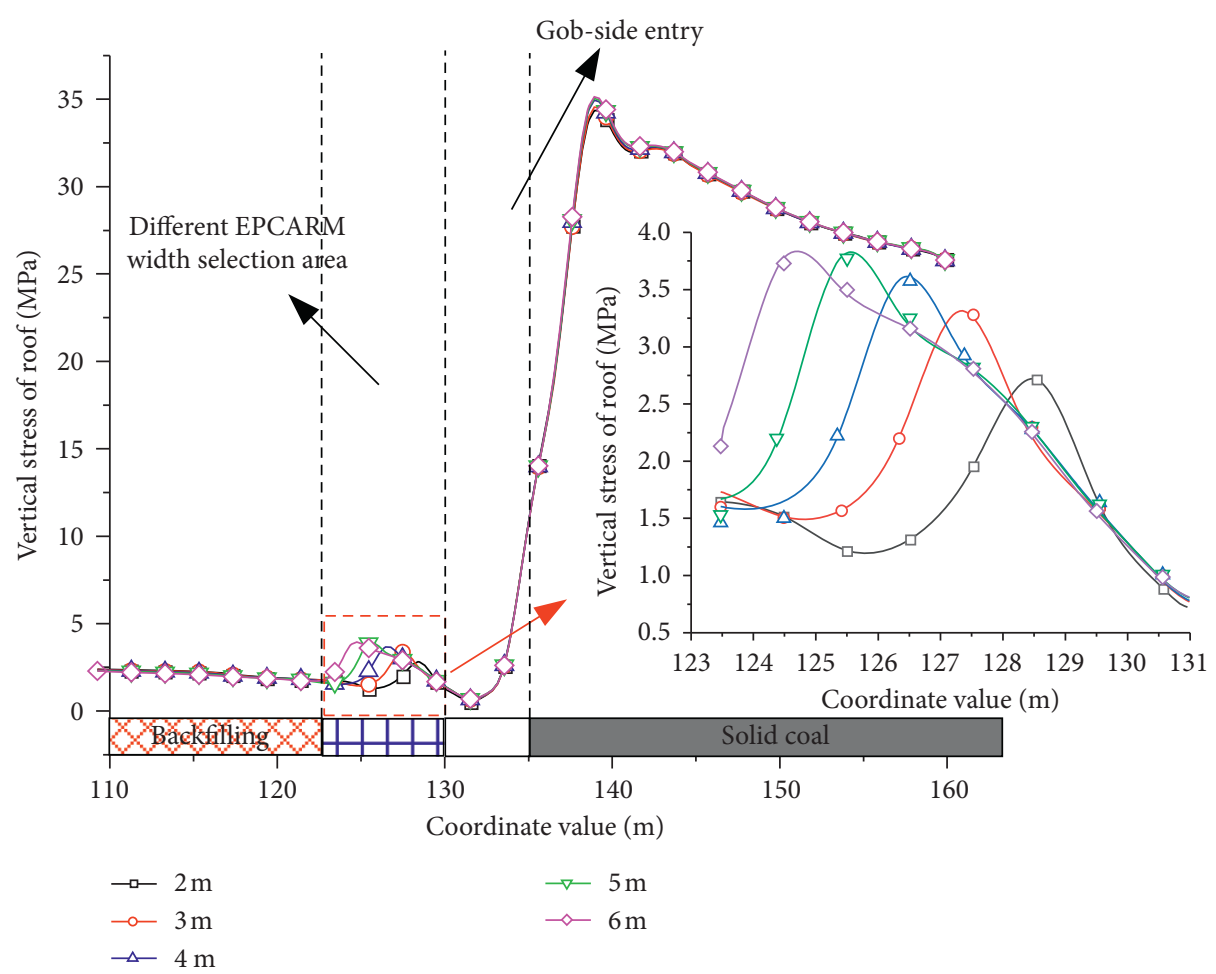

(a)

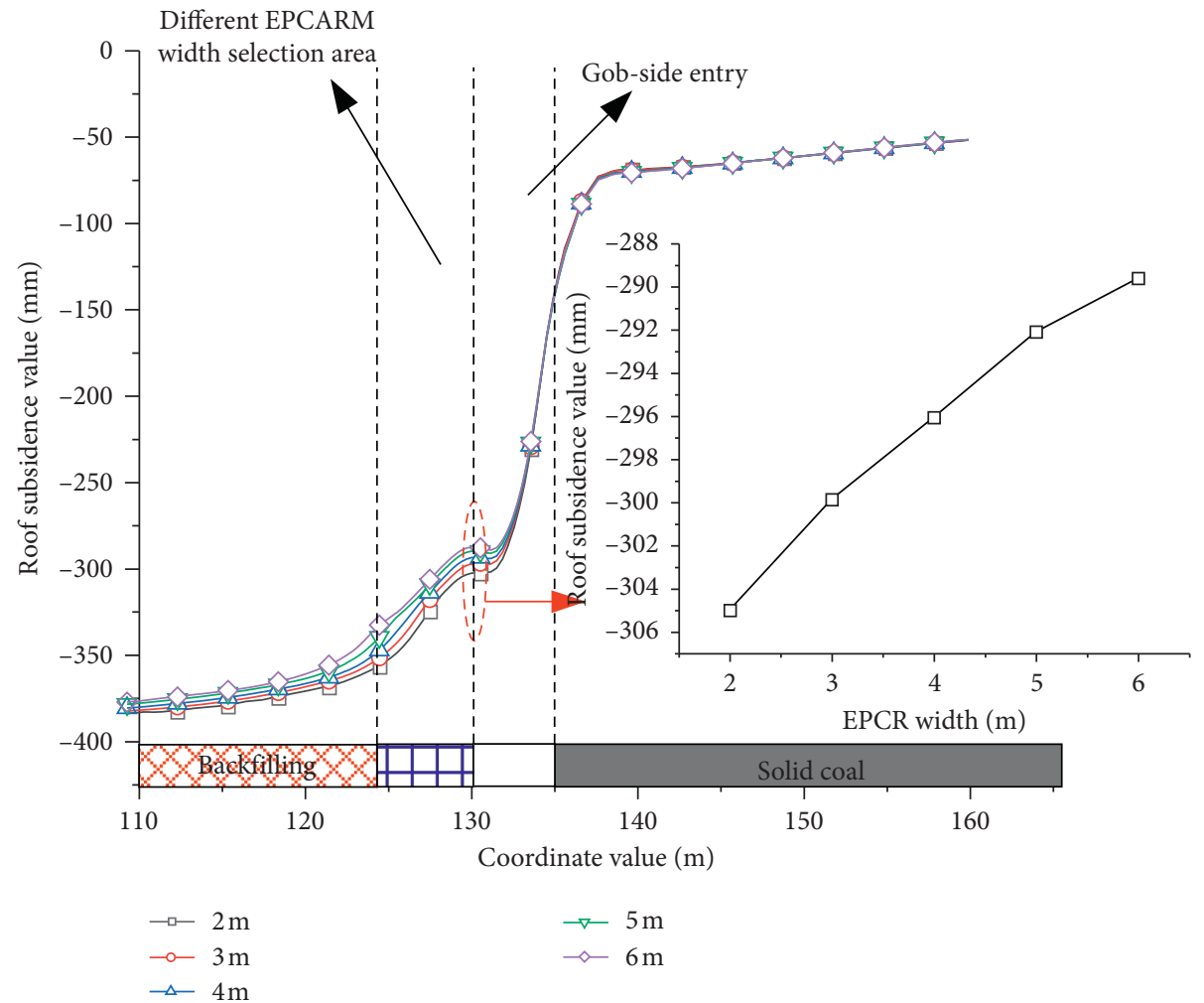

(b)

Figure 7: Roof deformation and stress variation for different widths of EPCARM. (a) Stress law. (b) Deformation law.

complex, including many devices, so it was recommended to adopt the GED technology of narrow coal pillars' retaining, which made it possible to optimize the entry support design, improve the support strength, and determine that the advance roof subsidence exceeds $0.2 \mathrm{~m}$ according to the numerical simulation. Backstopping started after entry 


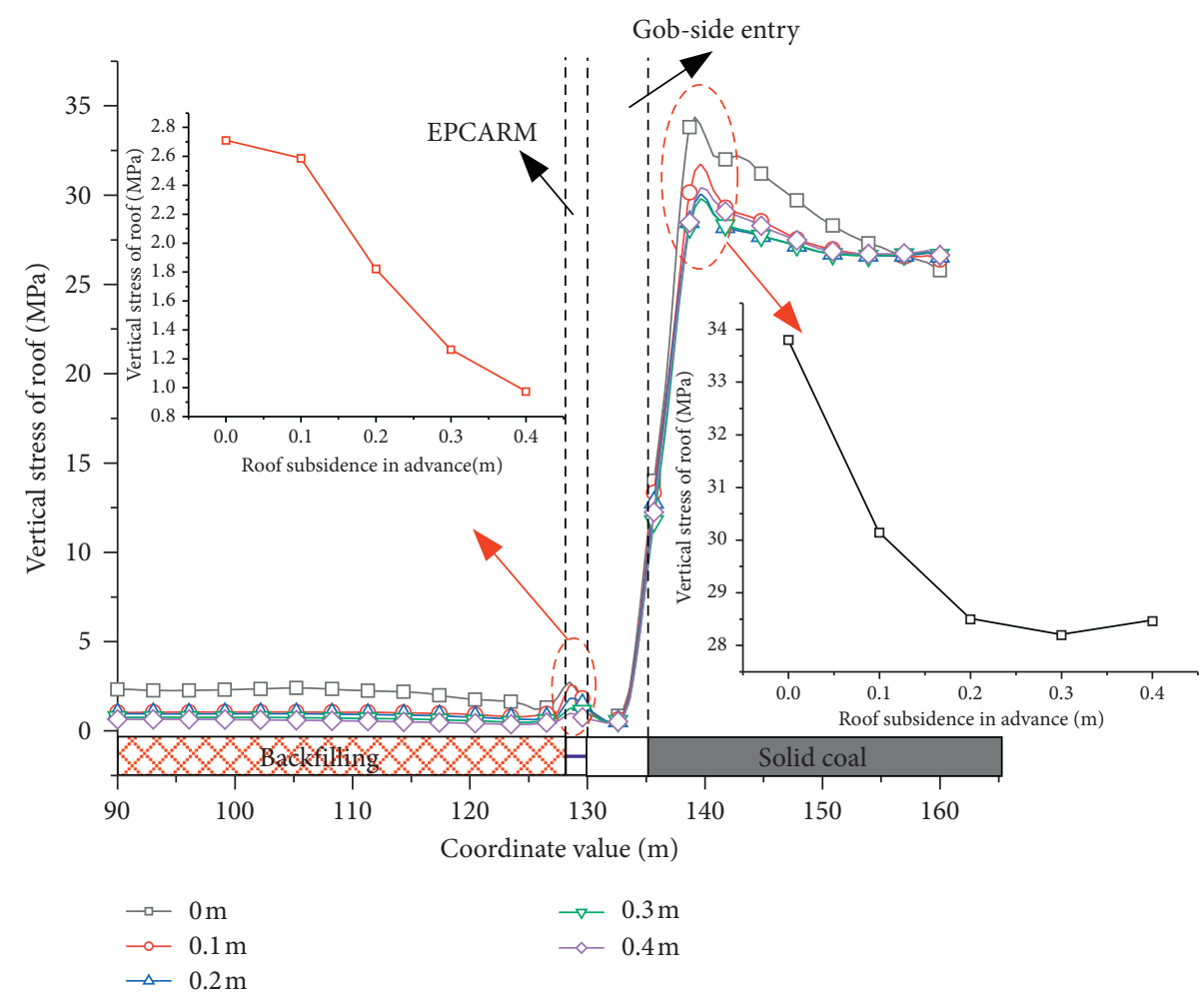

(a)

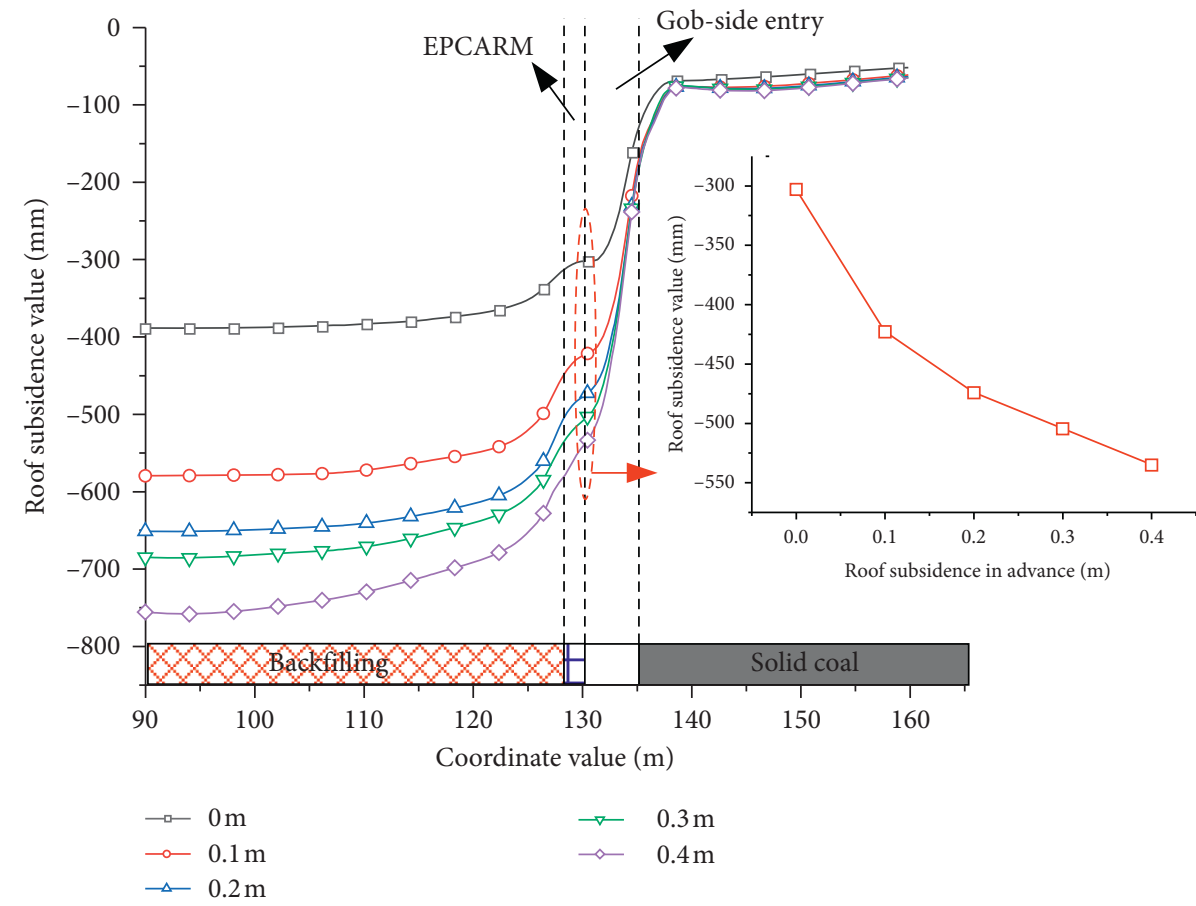

(b)

FIGURE 8: Roof deformation and stress variation of different roof advance subsidence values. (a) Stress law. (b) Deformation law.

excavation until the next working face. The surrounding rock control effect of the gob-side entry is shown in Figure 9. As indicated by the six deformation monitoring points, the maximum subsidence of the entry roof was $0.294 \mathrm{~m}$, and most of it reached $0.1 \mathrm{~m}$, which was consistent with the theoretical calculation results. Thus, the gob-side entry deformation fully met the requirements of safe mine production. 


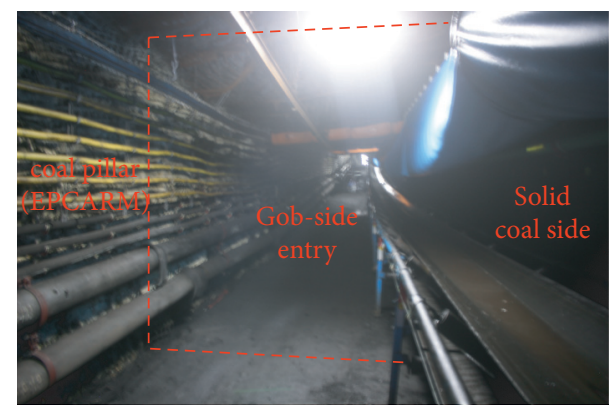

Figure 9: Control effect of the on-site surrounding rock.

\section{Conclusions}

The deformation characteristics of the surrounding rock with the gangue filling the entry retaining in the gob were analyzed. The mechanical model of the gob-side entry roof subsidence in backfill mining was established. Combined with numerical simulation and field investigation results, the following conclusions were drawn.

(1) Based on the Winkler elastic foundation assumption, a mechanical model of roof subsidence of gob-side entry filled with gangue was established. The effects of stiffness values of EPCARM and filling body in the gob, the EPCARM width, and the advance subsidence of filling on the entry deformation were analyzed. The calculation equation for roof subsidence of the filled gob-side entry was derived. The results show that goaf stiffness and advance roof subsidence significantly influence the entry deformation. The coal and rock stiffness had a relatively slight influence on the entry deformation, and the effect of coal and rock width on the entry deformation was weak.

(2) Using the numerical simulation method, the stress transfer pattern of gob-side entry with the deep filling was obtained. Increasing the foundation stiffness of the filling body in the goaf could transfer the stress of the coal rock mass and coal wall to the gob while increasing the foundation stiffness of the EPCARM. Thus, it could effectively control the entry roof subsidence, but it would also increase the stress. Therefore, to control the entry deformation, it is necessary to reasonably control the foundation stiffness of the gob filling body and the coal and rock mass so that the stress of the entry surrounding rock induces no large stress concentration.

(3) The engineering practice shows that the replacement of the entry protection gangue bag wall with the coal pillar yields the maximum roof subsidence of entry deformation of $0.294 \mathrm{~m}$ at the pillar width of $5 \mathrm{~m}$ and the advance subsidence of $0.2 \mathrm{~m}$, and most of the roof subsidence is about $0.1 \mathrm{~m}$, which is within a reasonable range and consistent with the predicted roof subsidence value. The accuracy of the proposed equation is confirmed, which provides a reference for the surrounding rock control of gob-side entry filled with gangue.

\section{Data Availability}

All the data used to support the findings of this study are available from the corresponding author upon request.

\section{Conflicts of Interest}

The authors declare that they have no conflicts of interest.

\section{Acknowledgments}

This work was supported by the National Key R\&D Program of China (2018YFC0604701), National Natural Science Foundation of China (51874281), and General Project of Jiangsu College Students' Innovation and Entrepreneurship Training Plan (201910290099Y). The authors gratefully acknowledge the financial support of the above-mentioned organizations.

\section{References}

[1] H. Xie, Y. Ju, S. Ren, F. Gao, J. Liu, and Y. Zhu, "Theoretical and technological exploration of deep in situ fluidized coal mining," Frontiers in Energy, vol. 13, no. 4, pp. 603-611, 2019.

[2] P. G. Ranjith, J. Zhao, M. Ju, R. V. S. De Silva, T. D. Rathnaweera, and A. K. M. S. Bandara, "Opportunities and challenges in deep mining: a brief review," Engineering, vol. 3, no. 4, pp. 546-551, 2017.

[3] D. Hao, S. Tu, and C. Zhang, "Experimental study on the effect of moisture content on bituminous coal porosity based on $3 \mathrm{D}$ reconstruction of computerized tomography," Natural Resources Research, vol. 29, no. 3, pp. 1657-1673, 2020.

[4] X. Hao, W. Du, Y. Zhao et al., "Dynamic tensile behaviour and crack propagation of coal under coupled static-dynamic loading," International Journal of Mining Science and Technology, vol. 30, no. 5, pp. 659-668, 2020.

[5] X. Hao, Y. Wei, K. Yang et al., "Anisotropy of crack initiation strength and damage strength of coal reservoirs," Petroleum Exploration and Development, vol. 48, no. 1, pp. 243-255, 2021.

[6] J. Lou, F. Gao, J. Yang et al., "Characteristics of evolution of mining-induced stress field in the longwall panel: insights from physical modeling," International Journal of Coal Science \& Technology, 2021.

[7] Z. Bian, X. Miao, S. Lei, S.-E. Chen, W. Wang, and S. Struthers, "The challenges of reusing mining and mineralprocessing wastes," Science, vol. 337, no. 6095, pp. 702-703, 2012.

[8] J. Hao, Y. Shi, J. Lin, X. Wang, and H. Xia, "The effects of backfill mining on strata movement rule and water inrush: a case study," Processes, vol. 7, no. 2, p. 66, 2019.

[9] Y.-C. Xue, T. Xu, P. L. P. Wasantha, T.-H. Yang, and T.-F. Fu, "Dynamic disaster control of backfill mining under thick magmatic rock in one side goaf: a case study," Journal of Central South University, vol. 27, no. 10, pp. 3103-3117, 2020.

[10] J. X. Zhang, X. J. Deng, X. Zhao, F. Ju, and B. Y. Li, "Effective control and performance measurement of solid waste backfill in coal mining," International Journal of Mining, Reclamation and Environment, vol. 31, no. 2, pp. 91-104, 2017.

[11] C. Weiyi, C. Zechao, Z. Dongsheng, W. Xufeng, C. Wenhao, and Z. Yazhou, "Roof filling control technology and application to mine roadway damage in small pit goaf," 
International Journal of Mining Science and Technology, vol. 29, pp. 477-482, 2019.

[12] Z. Zizheng, D. Min, B. Jianbiao, Y. Shuai, and Y. Xianyang, "Stability control of gob-side entry retained under the gob with close distance coal seams," International Journal of Mining Science and Technology, vol. 31, no. 2, pp. 321-332, 2020.

[13] F. Guorui and W. Pengfei, "Stress environment of entry driven along gob-side through numerical simulation incorporating the angle of break," International Journal of Mining Science and Technology, vol. 30, pp. 189-196, 2020.

[14] X. S. Liu, J. G. Ning, Y. L. Tan, Q. Xu, and D. Y. Fan, "Coordinated supporting method of gob-side entry retaining in coal mines and a case study with hard roof," Geomechanics and Engineering, vol. 15, pp. 1173-1182, 2018.

[15] C. Han, N. Zhang, J. Xue, J. Kan, and Y. Zhao, "Multiple and long-term disturbance of gob-side entry retaining by grouped roof collapse and an innovative adaptive technology," Rock Mechanics and Rock Engineering, vol. 52, no. 8, pp. 2761-2773, 2019.

[16] S. Tu, D. Hao, W. Li et al., "Construction of the theory and technology system of selective mining in "mining, dressing, backfilling and X" integrated mine," Journal of Mining \& Safety Engineering, vol. 37, pp. 81-92, 2020.

[17] X. Liu, X. Ji, and K. Miao, "Stress characteristics and stability analysis of coal (rock) body in deep back-filling gob side entry," Journal of Mining \& Safety Engineering, vol. 37, pp. 32-39, 2020.

[18] Q. Sun, J. Zhang, Y. Huang, and W. Yin, "Failure mechanism and deformation characteristics of gob-side entry retaining in solid backfill mining: a case study," Natural Resources Research, vol. 29, no. 4, pp. 2513-2527, 2020.

[19] Z. Zhang, H. Shimada, D. Qian, and T. Sasaoka, "Application of the retained gob-side gateroad in a deep underground coalmine," International Journal of Mining, Reclamation and Environment, vol. 30, no. 5, pp. 371-389, 2016.

[20] P. Wang, L. Ding, Y.-J. Ma et al., "A case study on gob-side entry retaining technology in the deep coal mine of xinjulong, China," Advances in Civil Engineering, vol. 2020, Article ID 8849093, 10 pages, 2020.

[21] F. Ju, Z. Chen, Q. Zhang, P. Huang, Y. Tai, and L. Lan, "Study on stability control of surrounding rock in retaining roadway along solid-filled coal mining," Journal of Mining \& Safety Engineering, vol. 32, pp. 936-942, 2015.

[22] X. Deng, C. Dong, Z. Yuan, N. Zhou, and W. Yin, "Deformation behavior of gob-side filling body of gob-side retaining entry in the deep backfilling workface," Journal of Mining \& Safety Engineering, vol. 37, pp. 62-72, 2020.

[23] Y. Huang, J. Zhang, Q. Zhang, and D. Zan, “Technology of gob-side entry retaining on its original position in fullymechanized coalface with solid material backfilling," Journal of China Coal Society, vol. 36, pp. 1624-1628, 2011.

[24] P. Gong, Surrounding Rock Deformation Mechanism and Application for Gob-Side Entry Retaining in Deep and Large Height Coal Seam with Fully Mechanized Gangue Backfilling Mining, China University Mining \& Technology., Xuzhou, China, 2018.

[25] Z. Chen, Y. Tai, H. Wang, W. Qi, B. Li, and X. Han, "Theoretical study on deep solid filling of meteorite belt and grouting combined road-way," Mining Research and Development, vol. 36, pp. 27-32, 2016.

[26] W. Yu, G. Wu, B. Pan, Q. Wu, and Z. Liao, "Experimental investigation of the mechanical properties of sandstone-coal-bolt specimens with different angles under conventional triaxial compression," International Journal of Geomechanics, vol. 21, Article ID 04021067, 2021.

[27] G. Wu, W. Yu, J. Zuo, and S. Du, "Experimental and theoretical investigation on mechanisms performance of the rockcoal-bolt (RCB) composite system," International Journal of Mining Science and Technology, vol. 30, no. 6, pp. 759-768, 2020.

[28] J. Wu, W. Zhou, H. Tao et al., "Research on failure characteristics and zoning control technology of thick-soft surrounding rock for deep gob-side entry retaining," Shock and Vibration, vol. 2020, Article ID 6613514, 14 pages, 2020.

[29] Z. Ma, C. Chen, X. Liang, A. Chen, and W. Song, "Field and numerical investigation on the stability of coal pillars of gobside entry driving with top coal," Arabian Journal of Geosciences, vol. 13, no. 22, 2020.

[30] L. Jiang, P. Kong, J. Shu, and K. Fan, "Numerical analysis of support designs based on a case study of a longwall entry," Rock Mechanics and Rock Engineering, vol. 52, no. 9, pp. 3373-3384, 2019.

[31] C. Hou and X. Li, "Stability principle of big and small structures of rock surrounding roadway driven along goaf in fully mechanized top coal caving face," Journal of China Coal Society, vol. 26, no. 1, pp. 1-7, 2001.

[32] J. Chen, L. Zhou, B. Xia, X. Su, and Z. Shen, "Numerical investigation of $3 \mathrm{D}$ distribution of mining-induced fractures in response to longwall mining," Natural Resources Research, vol. 30, no. 1, pp. 889-916, 2021.

[33] Q. Bai and S. Tu, "Numerical observations of the failure of a laminated and jointed roof and the effective of different support schemes: a case study," Environmental Earth Sciences, vol. 79, no. 10, 2020.

[34] Q. Bai, S. Tu, Y. Yuan, and F. Wang, "Back analysis of mining induced responses on the basis of goaf compaction theory," Journal of China University of Mining \& Technology, vol. 42, pp. 355-361, 2013.

[35] G. S. Esterhuizen and C. O. Karacan, "Development of numerical models to investigate permeability changes and gasemission around longwall mining panels," in Proceedings of the 40th U. S. Symposium on Rock Mechanics, pp. 25-26, Anchorage, AK, USA, June 2005.

[36] C. Zhang, S. Tu, and L. Zhang, "Field measurements of compaction seepage characteristics in longwall mining goaf," Natural Resources Research, vol. 29, no. 2, pp. 905-917, 2020.

[37] H. Yavuz, "An estimation method for cover pressure reestablishment distance and pressure distribution in the goaf of longwall coal mines," International Journal of Rock Mechanics and Mining Sciences, vol. 41, no. 2, pp. 193-205, 2004.

[38] S. Badr, U. Ozbay, S. Kieffer, and M. Salamon, "Three-dimensional strain softening modeling of deep longwall coal mine layouts," in Institute of Applied Geosciences, R. Brummer, P. Andrieux, C. Detournay, and R. Hart, Eds., pp. 233-239, August Aimé Balkema Publishers, Leiden, Netherlands, 2003.

[39] H. S. Mitri, R. Edrissi, and J. G. Henning, "Finite-element modeling of cable-bolted stopes in hard-rock underground mines," Transactions-Society for Mining Metallurgy and Exploration Incorporated, vol. 298, pp. 1897-1902, 1995.

[40] E. Hoek and E. T. Brown, "The Hoek-Brown failure criterion and GSI-2018 edition," Journal of Rock Mechanics and Geotechnical Engineering, vol. 11, no. 3, pp. 445-463, 2019.

[41] T. Li, G. Chen, Z. Qin, Q. Li, B. Cao, and Y. Liu, "The gob-side entry retaining with the high-water filling material in Xin'an coal mine," Geomechanics and Engineering, vol. 22, pp. 541552, 2020. 